\title{
ENDANGERMENT OF THE ELDERLY BY CRIME AND SOCIAL RESPONSE BASED ON COMMUNITY POLICING CONCEPT
}

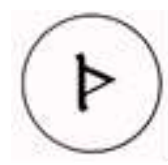

\begin{tabular}{|c|c|}
\hline $\begin{array}{l}\text { Svetlana Ristović, } \\
\text { Doctor of Science, research associate, } \\
\text { Professor of Vocational Studies, } \\
\text { E-mail: svetlana.ristovic@ @pu.edu.rs } \\
\text { https://orcid.org/0000-0002-3772-4745 } \\
\text { University of Criminal Investigation } \\
\text { and Police Studies, } \\
\text { Kara Dushana Street, } \\
\text { building 196, } \\
\text { office 174 } \\
\text { (Belgrade, Serbia). }\end{array}$ & $\begin{array}{r}\text { Citation: } \\
\text { Ristović, S. (2021). Endangerment of the Elderly by } \\
\text { Crime and Social Response Based on Community } \\
\text { Policing Concept. Social Communications: Theory } \\
\text { and Practice, Vol. 12(1), 118-127. } \\
\text { DOI: } 10.51423 / 2524-0471-2021-12-1-6 \\
\text { Retrieved from } \\
\text { https://new.comteka.com.ua/index.php/journal/articl } \\
\text { C) Ristović S., 2021 } \\
\text { (cc) EY EY }\end{array}$ \\
\hline
\end{tabular}

\section{ABSTRACT}

According to the average age of the population, Serbia is one of the oldest countries in the world, which results in increasing problems characteristic for the elderly population. One of them is the endangerment of the elderly by crime. In practice, not enough attention is paid to this issue, nor it is recognized as special and urgent, although due to the current number, and especially growing elderly population, their security problems will be greater and more present in society. Considering that elderly people a particularly vulnerable and discriminated category of the population, it is necessary to devise an adequate safety policy and establish an appropriate system of their protection. Community policing is recognized as a model of policing that can meet these requirements and adapt to the security needs of the elderly. This is because this concept is based on partnership with citizens and problem-oriented work. The police should be open to community representatives pointing out their needs and highlighting security priorities, and the police can identify problems with them and initiate mechanisms for joint action. Community policing is proactive policing in which formal and informal social control are mutually reinforcing one another.

The paper presents the most significant findings on endangerment by crime of the elderly aged 60 and over in the city of Belgrade from 2015 to 2019., in terms of: types of criminal offences, time, place, perpetrators and means of execution, as well as injured parties by gender. Also, the paper will show the organizational, functional and other advantages of community policing concept in relation to the traditional way of policing and try to answer whether its implementation can improve the safety of the elderly or adjust its operation to the security needs of this population.

Key words: endangerment of the elderly by crime, community policing, prevention, socially vulnerable groups. 


\title{
UGROŽENOST STARIH OSOBA KRIMINALOM I DRUŠTVENA REAKCIJA
} KONCEPTOM POLICIJE U ZAJEDNICI

\author{
Dr Svetlana Ristović \\ Kriminalističko-policijski univerzitet \\ (Belgrade, Serbia)
}

\section{Uvod}

Srbija nije pošteđena procesa demografskog starenja koji je postao globalan problem. Sa prosečnom starošću stanovništva od 43,3 godine Srbija se ubraja u red najstarijih zemalja na svetu, dok 20,7\% ukupnog stanovništva čine oni stariji od 65 godina (Republički zavod za statistiku, 2020). Shodno tome, u fokus sve više dolaze brojni i raznovrsni problemi koji su karakteristični za stariju populaciju. Jedan od njih je kriminal i viktimizacija starih lica. Velika je tamna brojka kriminala kada su u pitanju starije osobe, zbog čega su potrebna sistematičnija istraživanja o starim licima kao žrtvama kriminaliteta. Takođe, neophodno je da se problem starih lica i briga za njihove potrebe dodatno približi ne samo policiji, već i svim građanima. Za adekvatan pristup borbe protiv kriminala nad starim licima prepoznaje se policija u zajednici kao novi model policijskog delovanja koji se zasniva na partnerstvu sa građanima i problemski orijentisanom radu.

Ovo potencira potrebu da se u okviru koncepta policije u zajednici osmisli adekvatan odgovor u čijem će fokusu biti upravo starije osobe i njeno delovanje prilagodi potrebama i sposobnostima ove populacije, naročito imajući u vidu njenu nehomogenost (u pogledu pola, godina, bioloških, psihičkih, socijalnih, obrazovnih, kulturnih, ekonomskih osobenosti). Bezbednost zajednice i socijalna kohezija međusobno se ojačavaju. Policija u zajednici predstavlja proaktivnu policiju $u$ kojoj se formalna i neformalna socijalna kontrola međusobno jačaju (osnažuju), pomažući u smanjenju kriminala primenom preventivnih aktivnosti koje služe za promociju socijalne kohezije i smanjenje nereda u susedstvu (Sučić\& Karlović, 2017: 16).

"U suštini policijska organizacija treba da bude otvorena da predstavnici zajednice mogu da artikulišu svoje potrebe i istaknu bezbednosne prioritete, a da policija zajedno sa njima identifikuje probleme i pokrene mehanizme zajedničkog delovanja" (Nikač, 2019: 186). Shodno tome, policija u zajednici mora da afirmiše angažovanje najstarijih, po pitanju sopstvene bezbednosti i bezbednosti cele zajednice, pa je neophodno raditi na podizanju njihove svesti i znanja iz oblasti bezbednosti kako bi bili što bolji partneri policiji u ovoj borbi. Ovo je takav model rada koji podstiče i dozvoljava da dođe do izražaja njihovo znanje, iskustvo, sposobnost, i pre svega spremnost za saradnju sa policijom. U odnosu na starije ljude, bavljenje ugnjetavanjem i diskriminacijom uključuje prepoznavanje i borbu protiv ejdžističkih ideologija, politika i praksi koje utiču na pristup i pružanje usluga i podrške starijima (Wydall et al., 2018: 968).

\section{Svrha studije}

U radu će se pokušati dati odgovor da li primenom modela rada policije u zajednici i njegovih organizacionih, funkcionalnih i svih drugih prednosti u odnosu na tradicionalnu policiju, može dati adekvatan (i efikasan) odgovor na kriminal kojim je ugrožena starija populacija. Nakon najznačajnijih saznanja istraživanja o ugroženosti kriminalom starih lica u Beogradu, izložiće se mogućnosti poboljšanja bezbednosti starih lica primenom koncepta policije u zajednici odnosno ostvarivanjem njenih savremenih oblika.

\section{Rezultati i rasprava}




\section{Najznačajnija saznanja istraživanja o ugroženosti kriminalom starih lica u beogradu}

Ukupan broj oštećenih lica starosti 60 i više godina za period 2015-2019, u Republici Srbiji je 65775, od čega samo u Beogradu 18716, odnosno 28,4\%.

Od svih krivičnih dela (19424) učinjenih prema starijoj populaciji na teritoriji Beograda najčešće su zastupljena dela koja pripadaju grupi krivičnih dela protiv: života i tela (307 odnosno $1,6 \%$ ), slobode i prava čoveka i građanina (253 odnosno 1,3\%), braka i porodice (999 odnosno 5,14\%), imovine (15268 odnosno 78,6\% ), opšte sigurnosti ljudi i imovine (101 odnosno 0,52\%), bezbednosti javnog saobraćaja (1942 odnosno 10\% ) i javnog reda i mira (110 odnosno 0,57\%).

Stare osobe su naročito ugrožene imovinskim krivičnim delima, i to najčešće krivična dela krađe, teške krađe, razbojništva, prevare i neovlašćenog korišćenja tuđeg vozila. Stari su posebno ranjivi određenim vrstama krađa i prevara, koji se često nazivaju „krivična dela protiv starih“. Npr. pojedinci ulaze u kuće starih lica pod izgovorom da žele da pozajme telefon ili da dobiju čašu vode, a onda im kradu predmete ili prodaju robu ili usluge po daleko većim cenama (Lindgen\&NikolićRistanović, 2011: 68). Ili npr. za vreme aktuelne situacije sa korona virusom pojavili su se lažni volonteri koji navodno pomažu starima, a ustvari ih varaju i uzimaju novac (Večernje novosti (2020, 1. novembar)).

Zbog oslabljenih fizičkih i psihičkih sposobnosti (naročito onih od značaja za bezbednost u sabraćaju: sluh, vid, motoričke sposobnosti...) stari ljudi su veoma ugroženi kao učesnici u saobraćaju, što pokazuju i rezultati ovog istraživanja, po kome su krivična dela protiv bezbednosti javnog saobraćaja po brojnosti druga po redu kojima su stara lica najviše ugrožena. Donošenje novih i efikasnija primena postojećih zakonskih rešenja doprineće prevenciji i boljoj zaštiti najstarijih. Neophodna je edukacija i informisanje starih lica kako da povećaju svoju sigurnost u saobraćaju i umanje verovatnoću viktimizacije.

$\mathrm{Na}$ trećem mestu po brojnosti su krivična dela protiv braka i porodice. Udeo svih krivičnih dela učinjenih prema starim licima (19424) u odnosu na sva krivična dela evidentirana na teritorija grada Beograda (130417) iznosi 14,9\%. Najveći udeo je upravo kod grupe krivičnih dela protiv braka i porodice i iznosi $22,01 \%$, a neznatno se povećava kada se to upoređenje vrši samo u odnosu na krivično delo nasilje u porodici (4393) i iznosi 22,7\%. Rezultati ovog istraživanja eksplicitno ukazuju da treba usmeriti posebnu pažnju na stara lica kao žrtve porodičnog nasilja. Tim pre što je "poznato da starije osobe nerado govore o problemima, sukobima i stradanjima u sopstvenom domu. U tome i jeste težina položaja starih u porodici, jer im se čini da rešenje ne postoji, da je sve bezizgledno i izgubljeno. Nasilje nad starima u porodici je individualno, različito od čoveka do čoveka, od žrtve do počinioca" (Knežić, 2011: 70).

Opšti je trend u društvu povećanja broja krivičnog dela nasilja u porodici, ali naročito zabrinjava što se kao žrtve tih dela sve više pojavljuju stara lica. To je naročito zabrinjavajuće jer su u pitanju lica koja imaju 60 i više godina i koja najčešće zavise od članova svoje porodice. "Već nekoliko godina unazad podaci iz istraživanja koja su vršena u SAD ukazuju na to da su odrasla deca mnogo češće zlostavljači svojih ostarelih roditelja nego drugi članovi porodice" (Kostić\&Đorđević, 2004: 9). Stariji ljudi su često „skrivene“ žrtve nasilja u porodici. Jedno istraživanje otkriva da stariji ljudi doživljavaju nasilje u porodici dvostruko duže pre nego što zatraže pomoć od onih mlađih od 61 godine. (SafeLives UK, 2020).

Uvođenje krivičnog dela nasilje u porodici Izmenama Krivičnog zakona RS 2002. godine, uticalo je da nasilje nad ženama pokaže svoje prave razmere. Iako je nakon toga počelo sve više da se govori o porodičnom nasilju, čini se da se malo posvećuje pažnje nasilju nad starim osobama, koje je prisutnije nego što se pretpostavljalo (Rusac, 2006). Deo krivice zbog toga je i na starim osobama koje to ne prijavljuju zbog stida, emocionalne i finansijske zavisnosti od članova porodice, ali i na državnim organima koji ili nisu prepoznali ovaj problem ili mu se ne posvećuju dovoljno. 
Najviše krivičnih dela nad starim licima se izvrši u prepodnevnim časovima, i to od 10 do 11 časova (3305 tj. 17,2\%), za razliku od ostale populacije kada je to najčešće između ponoći i jednog časa posle ponoći. Stari su najmanje ugroženi od 4 do 5 ujutru (238). Ovaj pokazatelj ne iznenađuje jer su to prepodnevni časovi kada su stari ljudi nezaštićeni i obično sami (zato što sami žive ili su ostali ukućani na poslu ili u školi).

Stara lica su najčešće žrtve krivičnih dela koja se događaju u stanovima, kućama i drugim objektima za stanovanje (6160 tj. 31,7\%), a zatim na ulicama (5981 tj. 30,8\%) i ostalim mestima (4075 tj. 20,9\% ). Znatno manje u garažama i na parkinzima (1236 tj. 6,4\%), prodavnicama (711 tj. $3,7 \%)$ i vikendicama (581 tj. 3\%). Najmanje dela nad ovim licima je izvršeno u menjačnicama (16 tj. $0,08 \%$ ) i na pumpama (32 tj. 0,16\%). Ovaj podatak ne čudi jer stari ljudi usled bolesti i odsustva društvenih veza provode više vremena kod kuće nego što je to uobičajeno za ostalu populaciju. Ulice su, takođe, opasna mesta za stare ljude upravo zbog njihove predisponiranosti da postanu žrtve kriminala, kao i nemoći i nesposobnosti da se odbrane i suprotstave kriminalcu, na šta on i računa ( $\mathrm{tj}$. za njega je to manji rizik da bude uhvaćen i procesuiran).

Kada se učinioci krivičnih dela, gde se kao oštećena lica javljaju osobe starosti 60 i više godina, posmatraju po polnoj strukturi može se zaključiti da je znatno više učinilaca muškog pola, i to $87,1 \%$, a u pogledu starosne strukture najviše je onih koji imaju između 31 i 40 godina i mlađi (najviše onih od 21 do 30 godina). Starije osobe nisu nasumično viktimizirane. Zajedničko ovim izvršiocima jeste da oni stara lica biraju za žrtve upravo zbog njihove ranjivosti i "pogodnosti” da budu žrtve kriminaliteta.

Kao najčešće sredstvo izvršenja krivičnog dela nad licima starosti 60 i više godina javlja se fizička sila i ostala sredstva $(80 \%)$, zatim zanatski alati $(8,2 \%)$ i oružje i oruđe sa sečivom i oštro (3,9\%). Korišćenje drugih sredstava za izvršenje krivičnog dela je znatno manjeg i ujednačenog broja. Pošto je ova populacija izložena viktimizaciji i u porodici i van nje, na svim mestima i u svakom vremenskom periodu, ne čudi ni raznovrsnost sredstava izvršenja krivičnog dela nad njima. Imajući u vidu njihovu fizičku slabost i nemoć za očekivati je bilo da prednjači upotreba fizičke sile.

Stare osobe predstavljaju posebno ranjivu grupu, jer zbog svojih viktimogenih predispozicija lako postaju žrtve kriminala. Polna struktura oštećenih lica starosti od 60 i više godina života evidentiranih na teritoriji grada Beograda u istraživanom periodu, pokazuje da je više oštećeno lica muškog pola $(52,63 \%)$ i nešto manje ženskog pola $(47,34 \%)$.

Kada se sumiraju rezultati istraživanja dobija se da su stara lica (češće muškog nego ženskog pola) najviše ugrožena krivičnim delima protiv imovine, koja se najčešće izvrše od 10 do 11 časova prepodne, u stanovima, kućama i drugim objektima za stanovanje, od strane izvršioca muškog pola koji ima između 31 i 40 godina, upotrebom fizičke sile.

Ovakvo saznanje omogućava sačinjavanje kvalitetnih (i preciznih) preventinih programa (koji se isključivo odnose na starije osobe), kao i kontinuitet u njihovoj primeni usled stila života i načina ponašanja starih lica koji je predvidljiv.

Klasična policija se uglavnom ne bavi pitanjima i brigom o potrebama žrtava. Sa starim osobama koje su žrtve kriminala potreban je drugačiji pristup. Policija u zajednici je koncept koji to može da nadomesti, jer u svom programu delovanja ima i predviđa posebne mere, aktivnosti i sadržaje koji se bave pitanjima žrtava, a naročito onih najugroženijih. U nastavku rada će biti izložene mogućnosti i prednosti ovog modela rada policije i konkretni predlozi za poboljšanje bezbednosti starih lica sa stanovišta policije u zajednici.

\section{Poboljšanje bezbednosti starih lica ostvarivanjem savremenih oblika policije u zajednici}

"Društvo nije svesno svoje uloge i odgovornosti u sprečavanju i prevenciji nasilja nad starijima, kao ni potrebe za većim brojem istraživanja i isticanjem ovog problema kao problema 
kome može biti izložen nezanemarljiv deo populacije starijih osoba" (Risović et al., 2018: 362). Posebnu odgovornost $\mathrm{u}$ tom smislu snosi policija. Prihvatanjem policije u zajednici kao novog modela rada otvara se mogućnost za adekvatan odgovor na ovaj bezbednosni izazov imajući u vidu njegove osnovne komponente i principe rada, usvojen sistem vrednosti i oblike ostvarivanja. Osnov za ovakvu tvrdnju nalazi se, između ostalog, i u solidnom teorijskom i praktičnom utemeljenju koje proizilazi iz dobrih iskustava zemalja u kojima je ovaj model već implementiran. U procesu prihvatanja i implementacije koncepta policije u zajednici kod nas su, još 2006. godine, u okviru projekta "Odnos policije i manjinskih i socijalno ranjivih grupa" (Projekat Odnos policije i manjinskih i socijalno ranjivih grupa, 2006) prepoznate manjinske i socijalno ranjive grupe kojima treba posvetiti posebnu pažnju u okviru ovog modela policijskog delovanja. To su: pripadnici etničkih manjina, pripadnici manjinskih seksualnih opredeljenja, žene, najmlađi i najstariji predstavnici populacije, lica sa invaliditetom, pripadnici manjinskih, političkih i religijskih uverenja. Međutim, iako su doneti prvi dokumenti i projekti u vezi sa tim, preduzete različite aktivnosti i kampanje koje se bave najosetljivijim grupama (najčešće su to dece, žene, LGBT), to je i dalje nedovoljno, jer su konkretne akcije koje se odnose isključivo na stariju populaciju izostale.

U nastavku rada sagledava se moguće poboljšanje bezbednosti starih lica kroz ostvarivanje ovog koncepta i njegovih savremenih oblika rada.

Kako se tradicionalan način delovanja policije pokazao kao nedovoljno efikasan, policija u zajednici nudi nov pristup u formi problemski orijentisanog rada. Goldstein ga definiše kao „rad koji prepoznaje različite vrste kriminala podstaknutih osnovnim problemima koji postoje u celoj zajednici i koji se rešavaju kroz delotvorne strategije za rešavanje problema“ (Goldstein, 1990: 1823). Goldstein predlože da policajci takvim incidentima trebaju pristupiti kao ,problemima koje treba rešiti“, a ne kao potencijalnim zločinima. Postoje tri ključna elementa ovog pristupa: 1) Jasnije odrediti problem. 2) Istražiti problem, tj. sakupiti i analizirati osnovne podatke o specifičnom problemu. 3) Tražiti alternative trenutnim načinima odgovora. Traže se inovativna rešenja koja bi se proširila izvan policije ili sistema krivičnog zakonodavstva (što uključuje različite strategije preventivnog delovanja policije) (Roberg, Crank\&Kuykendall, 2004: 87).

Pristup putem problemski orijentisanog rada čija je suština da se delovanje policije usmeri na uslove i uzroke kriminala i druge oblike društveno nepoželjnog ponašanja, zahteva sačinjavanje akcionih planova, definisanje kratkoričnih i drugoročnih ciljeva i prioriteta, preduzimanje konkretnih mera i radnji, određivanje internih i eksternih resursa, oblika saradnje sa drugim subjektima, i na kraju, rokove i načine njegove evaluacije (Ristović, 2015).

Ovakav način delovanja omogućava sveobuhvatan pristup u rešavanju bezbednosnih problema čitave populacije, pa i njenog nastarijeg dela. U osnovi, rad policije u zajednici zahteva da policajci budu kreativni prilikom osmišljavanja rešenja bezbednosnih problema zajednice, što zahteva značajnu dozu inventivnosti. Kada dođe do efikasnog rešavanja problema, rešenja koja prevazilaze tradicionalne reakcije policije postaju norma (Kappeler\&Gaines, 2009: 17-18).

Da bi policija u zajednici bila efikasna u rešavanju bezbednosnih problema starije populacije neophodno je izgraditi poverenje i uspostaviti partnerstvo između policije i starijih osoba. Da bi se izgradili partnerstvo policija mora da istupa sa povećanom brigom za starije i sprovodi projekte uspostavljanja saradnje i pridobijanja starih osoba činjenjem nekih socijalnih usluga i rešavanjem nekih njihovih problema ili strahova u vezi sa kriminalom. U osnovi je ideja o saradnji policije $\mathrm{i}$ starijih osoba u rešavanju njihovih osnovnih bezbednosnih problema, pri čemu se stavovi i očekivanja starih moraju uzimati kao relevantan faktor koji u značajnoj meri treba da utiče na karakter i prioritet policijskog delovanja. Uspostavljanje partnerstva treba da označi prekretnicu u odnosu policije i starih ljudi i da suštinski promeni pristup policije prema ovoj populaciji i rešavanju njenih problema. 
Partnerstvo doprinosi smanjenju straha od kriminala koji kao složen društveni fenomen može imati štetne efekte na veći broj ljudi od konkretno izvršenog krivičnog dela. Generalno, kako ljudi stare imaju veći strah od kriminala, što direktno utiče na kvalitet života. Strah od kriminala direktna je odgovornost policije koja ima nadležnost da obezbedi da se ljudi osećaju sigurno. Strah od kriminala zahteva posebno angažovanje policije u zajednici kroz različite programe, koji se mogu odnositi na: pružanje informacija starijim osobama o kriminalu, decentralizovane operacije kroz mini-policijske stanice i bliskiju saradnju sa starim osobama kroz pešačke patrole, uspostavljanje ponovnog kontaka sa žrtvama i drugi programi koji insistiraju na kvalitetnijem kontaktu sa starim licima. Policija u zajednici koja potencira partnerstvo i direktan odnos sa zajednicom ima predispozicije da smanji strah od kriminala kod starih ljudi i posebnu odgovornost da predloži nacionalni program osmišljen da smanji kriminal i strah od kriminala među starim licima (Kappeler\&Gaines, 2011: 274-275).

Policija u zajednici insistira na partnerstvu ne samo sa građanima, već i sa državnim organima, organizacijama, institucijama i drugim pravnim licima. Policija sa njima uspostavlja kontakt, a potom i saradnju u rešavanju problema, pri čemu svako daje doprinos iz okvira svoje stručnosti i nadležnosti. U osnovi ove ideje je spoznaja da policija ne može sama da rešava probleme i neophodno je povezivanje sa drugim institucijama tj. multiagencijski pristup. Konkretno $\mathrm{u}$ slučaju bezbednosnih problema starije populacije, treba uspostaviti intenzivne i direktne komunikacije i saradnju između ministarstava koja su direktno ili indirektno nadležna za problematiku starije populacije (zdravlja, penziono, kulturu i informisanje i dr.). Ta saradnja treba da preraste $\mathrm{u}$ akciono partnerstvo, koje se zasniva na zajednički utvrđenim planovima sa jasno utvrđenim sadržajem, oblicima, nosiocima i rokovima njegovog ostvarivanja. Treba ustaliti praksu redovne evaluacije ovih planova, po unapred utvrđenim validnim indikatorima. Saradnju treba da uspostave i drugi organi, institucije, nevladin sektor, udruženja građana i njihove asocijacije radi stvaranja partnerstva u rešavanju bezbednosnih problema starih. U svaki vid saradnje neophodno je uključiti i organizacije starih i organizacije za stare, poput udruženja penzionera, Pokreta trećeg doba Srbije, Gerontološkog društva Srbije i mnoga druga.

Potpunije i serioznije sagledavanje demografske situacije i analiziranje projekcije starenja stanovništva, kao i ekonomske, socijalne i kulturološke osobenosti starije populacije u lokalnoj zajednici, a posebno njihova porodična domaćinstva, doprineće da se u skladu sa dobijenim pokazateljima i saznanjima osmisli organizacija i sadržaj rada policije. Policija u zajednici je prepoznala važnost organizacione strukture za efikasno delovanje u lokalnoj zajednici. Promene koje se odnose na organizacionu strukturu policije su različite i po značaju se ističu sledeće promene: decentralizacija, smanjenje hijerarhijskih nivoa komandovanja, timski rad i uključivanje volontera (Cordner, 1998: 55-56). Ove karakteristike organizacione sutrukture policije u zajednici nameću (preporučuju) se kao adekvatne za reagovanje i odgovor na kriminal kojim su ugrožena stara lica.

Decentralizacija omogućava da se poslovi i zadaci policije prilagođavaju konkretnoj lokalnoj zajednici i njenim bezbednosnim problemima. Omogućava neposredan kontakt između policijskih službenika i građana (starijih lica) i podstiče dvosmernu komunikaciju i saradnju. Nadalje, decentralizovan način rada podrazumeva ustaljenost policijskih službenika na određenom području dugi niz godina što im omogućava da upoznaju lokalnu zajednicu i prilike u njoj, građane i njihove probleme. Na taj način mogu dobro da upoznaju područje svog delovanja i adekvatno odgovore primenom problemski orijentisanog rada.

Prepoznata krivična dela kojima su stara lica najviše ugrožena, mesto i vreme njihovog izvršenja mogu da posluže kao kriterijum za određenje rasporeda i sadržaja rada policije, organizovanje smenskog rada, pešačkih i motornih patrola i drugih savremenih oblika rada policije u zajednici: implementacija policajca u susedstvu, program "od vrata do vrata", osnivanje 
policijskih ministanica, projekti nadzora nad susedstvom, stvaranje "sigurnosne mreže", zajednički sastanci policije i starijih sugrađana, programi razvoja komunikacije policije sa starim licima, otvaranje kancelarije u policijskoj stanici ili mesnoj zajednici u kojoj bi policijski službenici primali starije osobe, razgovarale sa njima i pružali im savete i pomoć, otvaranje SOS linije pri policijskoj stanici samo za stara lica i njihove bezbednosne probleme, kao i drugi proaktivni oblici rada policije.

Istovremeno, smanjenje hijerarhijskih nivoa rukovođenja donosi veća ovlašćenja i odgovornosti nižih nivoa rukovodilaca, pa i samih policijskih službenika na terenu odnosno pozornika. S obzirom da najbolje poznaju situaciju na terenu, oni mogu i trebaju da samostalno organizuju i osmišljavaju sadržaj svog rada i donose konkretne odluke.

Dobro poznavanje svog područja delovanja otvara mogućnost za policajce koji primenjuju model rada policije u zajednici da preduzimaju preventivne mere i aktivnosti, kao i da pokreću inicijative i daju predloge za sačinjavanje konkretnih preventivnih programa za koja su stara lica posebno zainteresovana. Ovi napori ne trebaju biti usmereni samo na osmišljavanje i implementaciju novih preventivnih programa, već posebno, na evaluaciju već primenjenih mera $\mathrm{i}$ aktivnosti, kao i primenu primera dobre, naše i strane, prakse, pa i inovativnih i nestandardnih rešenja (npr. postavljanje znakova obaveštenja vozačima da uspore pored doma ili kluba za stare, parkova, šetališta, kvartova koje koriste stari, kao što se to čini za decu pored škola).

Zbog stalnog prisustva na terenu i neposrednog kontakta sa starim licima pozornik treba da radi na njihovom podsticanju na samopomoć i samozaštitu, podučavanju da prijave policiji svako ugrožavanje kriminalom ili drugim društveno neprihvatljivim ponašanjem, zatim, da održava zajedničke sastanke, uključuje stara lica u kreiranje bezbednosne politike u lokalnoj zajednici, kontinuirano ih informiše o stanju kriminalteta u njihovoj lokalnoj zajednici i upoznaje sa mogućnostima učešća u različitim preventivnim akcijama i saradnji sa policijom, daje pravne ili druge vrste saveta starim licima žrtvama kriminala.

Sledeća karakteristika policijske organizacije shodno modelu rada policije u zajednici je timski rad, kao i uključivanje volontera.

Radi uspešnog timskog rada neophodna je integracija starih lica u zajednicu. I to naročito obezbeđivanjem učešća starije populacije u kreiranje bezbednosne politike u lokalnoj zajednici; usvajanjem programa uspostavljanja pozitivnih i unapređenja postojećih relacija između policije i starijih građana; donošenje odluka kroz učešće u radu Saveta za bezbednost, neposredna komunikacija sa policajcima, prisustvo sastancima, članstvo u savetodavnim telima i sl. Policija u zajednici kao model rada policije je otvorena za uključivanje (doprinos) volontera koji bi kroz zajedničke osmišljene aktivnosti raditi na unapređenju sigurnosti i kvaliteta života starije populacije. Njihove godine, usamljenost, slabost i nemogućnost da se odbrane su dodatni motiv počinilaca krivičnih dela protiv starih. To nameće potrebu uspostavljanja mreže podrške stvarnim i potencijalnim žrtvama koje pripadaju kategoriji starih lica, sačinjenu od volontera, a sa kojima bi policija ostvarila intenzivnu saradnju. "Da bi volonterskog rada bilo više potrebno je da dobije odgovarajuće mesto u našem vrednosnom sistemu. Neophodna je permanentna edukacija volontera, organizovanje okruglih stolova, seminara, masovnih akcija, dobro osmišljenih kampanja, formiranje volonterskih centara i mreže volontera" (Dinić, 2009: 112). U mrežu volontera treba uključiti i same starije osobe koji bi pomagali zajednici i jedni drugima, svako pružanjem doprinosa u okviru svojih mogućnosti i sposobnosti.

$\mathrm{Za}$ proboljšanje bezbednosti starije populacije nezaobilazno je pitanje edukacije, kako policije, tako i starih osoba. Policije u pogledu bezbednosnih problema starih lica i pristupa u radu i komunikaciji sa ovom populacijom, a starih sa stanovišta podiznja bezbednosne svesti i poboljšanja bezbednosne kulture, kao i potrebi saradnje sa policijom.

U okviru modela rada policije u zajednici neophodno je selektovati određen broj policajaca koji će se primarno baviti bezbednosnim potrebama starijih osoba. Potrebno je organizovati 
njihovu teorijsku i praktičnu obuku i u skladu sa ovim potrebama izvršiti izmene i dopune nastavnog sadržaja predmeta Policija u zajednici, koji se već izučava na ustanovama policijskog školstva, npr. "otkrivanje i pomoć žrtvama nasilja nad starijima koji bi obuhvatio module dizajnirane da poboljšaju razumevanje policijskih službenika o prirodi zlostavljanja starijih, prirodi procesa starenja, ulozi policije u mreži socijalnih i pravnih usluga, etičkim i praktičnim pitanjima koja vode usvajanje odluka u slučajevima zlostavljanja starih osoba" (Payne, 2011: 166). Zatim, potrebno je propisati sveobuhvatne i jasne instrukcije, u pogledu postupanja sa starim licima uopšte, posebno ako su žrtve. Mora se raditi na uspostavljanju i razvijanju kulture dijaloga sa starim osobama, kao i, uspostavljanju preciznih instrukcija za pripadnike policije u pogledu postupanja sa starim licima uopšte, a posebno ako su žrtve. Možemo se koristiti stranim iskustvima, jer u svetu policajci već prolaze edukacione kurseve kako bi se osposobili da lakše razumeju stare osobe, uoče njihove bezbednosne potrebe, uspešnije kontaktiraju sa njima, motivišu ih na saradnju, angažuju volontere i kroz zajednički osmišljene aktivnosti unaprede nivo njihove sigurnosti i kvalitet života (Dempsey\&Forst, 2005: 202-207).

Stara lica takođe treba da imaju edukaciju kako bi im se podigla bezbednosna svest i afirmisalo njihovo angažovanje po pitanju sopstvene bezbednosti i bezbednosti cele zajednice. Konkretno, to bi se moglo odnositi na obuku o samozaštiti i samopomoći, fizičko-tehničkom obezbeđenju stana (alarmi, video nadzor i sl.), načinu komuniciranja sa nepoznatim licima, kako da postupaju u slučaju neposredne opasnosti, korišćenju novih tehnologija (mobilni, kompjuteri i sl.) i uopšte bezbednom ponašanju i izbegavanju mogućnosti da postanu žrtve krivičnih dela.

Edukacija mora biti potkrepljena posebnim naučnim istraživanjima o ugroženosti starih lica kriminalom. Ovaj stav nalazi uporište u konceptu policije u zajednici jer on podrazumeva naučna, nezavisna i kritička istraživanja rada policije. Naučna istraživanja, koja se mogu obavljati periodično ili stalno, merenje efekata policijskog rada i komparacija pribavljenih podataka po brojnim parametrima daju "relativno upotrebljive rezultate i pokazatelje, pa se saglasno tome utvrđuju projekcije razvoja pro futuro i predlažu mere za unapređenje rada policije i dalje približavanje zajednici" (Nikač, 2019: 118). Rezultati istraživanja ugroženosti starije populacije kriminalom doprineli bi stvaranju jedne sveukupne slike u opštoj, stručnoj i naučnoj javnosti o viktimitetu starih osoba. Takođe, doprinelo bi stvaranju zajedničke platforme za buduće, naučno proverene i preporučene, akcije i mere u borbi protiv kriminala kojim su stara lica najugroženija. Pored toga, ova istraživanja bi poslužila za propisivanje posebnih procedura i donošenje proverenih protokola o postupanju prema starim licima kao posebno ranjivoj kategoriji ljudi kako ih policija u zajednici i prepoznaje i daje im posebno mesto u postupku svog ostvarivanja. Predmeti istraživanja mogu biti brojni i mogu obuhvatiti, npr. načine ostvarivanja saradnje starijih osoba i policije, prigovore i predstavke starih lica na rad policije, zatim samopomoć i samozaštita starih lica, mogućnosti i sadržaje uključivanja starije populacije u preventivne programe, ocenjivanje rada policijskih službenika sa starim licima, stavove starije populacije prema policiji, kao i stavove policije prema ovoj populaciji, međusobna komunikacija, sadržaj rada i raspored radnog vremena policajaca i sl. Rezultati i saznanja ovakvih istraživanja ne samo da doprinose edukaciji policijskih službenika i njihovoj kreativnosti u rešavanju bezbednosnih problema, već doprinose i razvoju kritičkog pristupa radu policije.

\section{Zaključak}

Model rada policije u zajednici može dati adekvatan odgovor u sprečavanju kriminala kojim su ugrožene starije osobe i uspešna u smanjenju njihove viktimizacije. Pre svega zbog toga što nije statičan, već promenljiv i prilagodljiv način rada policije, koji potencira kreativan odgovor na identifikovane probleme u zajednici. Ovaj koncept (može i treba da) objedinjuje različite strategije i 
taktike, osim toga, dozvoljava eksperimentisanje sa različitim preventivnim programima (merama i radnjama) koji neposredno uključuju (starije) građane u njihovu realizaciju. S obzirom da stare osobe dolaze iz svih društvenih slojeva, različitog su obrazovanja, materijalnog statusa, porekla, njihovo znanje i iskustvo mogu biti bogat izvor inovacija i kreativnosti (npr. njihovo iskustvo iz vremena društvene-samozaštite). U tom smislu policija mora da prevaziđe prepreke koji proizilaze iz njenih organizacionih i funkcionalnih karakteristika $i$ da odlučnije mobiliše zajednicu da učestvuje $\mathrm{u}$ borbi protiv kriminala stvaranjem efikasnog partnerstva sa drugim društvenim subjektima i uspostavaljanjem dvosmernih komunikacija sa građanima radi razmene informacija.

Prvi korak ovog koncepta na tom putu, ali i celokupnog društva, jeste da doprinese društvenoj vidljivosti i visokoj svesti o starim ljudima kao posebnoj kategoriji žrtava kriminala u Srbiji.

\section{REFERENCE}

Cordner, G. (1998). Community Policing, Elements and Effects, In: Alpert, G. P., Piquero A., Community Policing Contemporary Readings, Waveland Pr Inc.

Dempsey, J., Forst, L. (2005). An Introduction to Policing, Thomson Wadsworth.

Dinić, D. (2009). Socijalna država i volonterski rad, Politička revija [Political magazine], 20(2), 89-116.

Goldstein, H. (1990). Problem-Oriented Policing, New York: McGraw-Hill.

Kappeler, V., Gaines, L. (2009). Community Policing, A Contemporary Perspective, $5^{\text {th }}$ Edition, Anderson Publishing.

Kappeler, V., Gaines, L. (2011). Community Policing, A Contemporary Perspective, $6^{\text {th }}$ Edition, Anderson Publishing.

Knežić, B. (2011). Ne samo koliko živeti [Not just how long to live]. Beograd: Institut za kriminološka i sociološka istraživanja.

Kostić, M., Đorđević, R. (2004). Viktimizacija starih osoba kao pripadnika posebne marginalne grupe, Temida [Themis], 7(2), 3-11.

Lindgren, M., Nikolić-Ristanović, V. (2011). Žrtve kriminaliteta: međunarodni kontekst i situacija u Srbiji [Victims of crime: international context and situation in Serbia]. Beograd: Organizacija za evropsku bezbednost i saradnju, Misija u Srbiji.

Nikač, Ž., (2019). Policija u zajednici [Community policing], Kriminalističko-policijski univerzitet, Beograd.

Payne, B. K. (2011). Crime and Elder Abuse: An Integrated Perspective. Vol. 3rd ed. Charles C Thomas Publisher, LTD, Illinois, USA.

Projekat Odnos policije i manjinskih $i$ socijalno ranjivih grupa [The relationship between the police and minority and socially vulnerable groups], završni izveštaj prve faze projekta, OSCE, British Council i MUP RS, Beograd, 2006.

Risović, K., Rusac, S., Todorović, N. (2018). Faktori rizika povezani sa nasiljem nad starijim osobama u porodici, Temida [Themis], 21(3), 362-383.

Ristović, S. (2015). Policija u zajednici i suprotstavljanje savremenim oblicima kriminaliteta [Community policing and combating modern forms of crime]. Kriminalističko-policijska akademija, Fondacija Hans Zajdel, Beograd, 101-111.

Roberg, R., Crank, J., Kuykendall, J. (2004). Policija i društvo [Police and society], Sarajevo, Office of Public Affairs Embasy of the United States of America.

Rusac, S. (2006). Nasilje nad starijim osobama. Ljetopis socijalnog rada [Annual of social work]. Zagreb, 13(2), 331-346.

Republički zavod za statistiku [Republic Bureau of Statistics]. Preuzeto 3. Novembar sa 2020 https://www.stat.gov.rs/ 
Sučić, I., Karlović, R., (2017). Community Policing in Support of Social Cohesion, in Community Policing - A European Perspective Strategies, Best Practices and Guidelines, Springer International Publishing AG.

SafeLives UK (2020). Safe Later Lives: Older people and domestic abuse, Spotlights Report, available online at: http://www.safelives.org.uk/file/safe-later-lives-older-people-anddomestic-abusepdf, 07.11.2020.

Wydall, S., Clarke, A., Williams, J. \& Zerk, R. (2018). Domestic Abuse and Elder Abuse in Wales: A Tale of Two Initiatives. British Journal of Social Work, 48(4), 962-981. https://doi.org/10.1093/bjsw/bcy056

Lažni volonteri VARAJU starije građane, koriste epidemiju da im uzmu novac (n.d.) [Fake volunteers CHEAT senior citizens, use the epidemic to take their money]. Preuzeto 1. Novembar $2020 \mathrm{sa}$ https://www.novosti.rs/vesti/naslovna/drustvo/aktuelno.290.html:8534 94Lazni-volonteri-VARAJU-starije-gradjane-koriste-epidemiju-da-im-uzmu-novac

\title{
UGROŽENOST STARIH OSOBA KRIMINALOM I DRUŠTVENA REAKCIJA KONCEPTOM POLICIJE U ZAJEDNICI
}

\author{
Dr Svetlana Ristović \\ https://orcid.org/0000-0002-3772-4745 \\ svetlana.ristovic@kpu.edu.rs \\ Kriminalističko-policijski univerzitet, \\ Ulica Cara Dušana, zgrada 196, ured. 174 \\ (Belgrade, Serbia)
}

\section{Apstrakt}

Prema prosečnoj starosti stanovništva Srbija je jedna od najstarijih zemalja na svetu usled čega su sve očigledniji problemi koji su karakteristični za stariju populaciju. Jedan od njih je i ugroženost starih lica kriminalom. U praksi se ne posvećuje dovoljno pažnje ovoj problematici, niti je ona prepoznata kao posebna $i$ urgentna, iako će zbog trenutne brojnosti, a naročito tendencije porasta starije populacije, njihovi bezbednosni problemi, biti sve veći i prisutniji u društvu. S obzirom da su starija lica posebno ranjiva $i$ diskriminisana kategorija stanovništva neophodno je osmisliti adekvatnu bezbednosnu politiku i uspostaviti odgovarajući sistem njihove zaštite. Policija u zajednici se prepoznaje kao model rada policije koji može da odgovori ovim zahtevima i prilagodi bezbednosnim potrebama starih lica. Ovo zbog toga što se ovaj koncept zasniva na partnerstvu sa građanima i problemski orijentisanom radu. Policija treba da bude otvorena da predstavnici zajednice mogu da ukažu na svoje potrebe i istaknu bezbednosne prioritete, a da policija zajedno sa njima identifikuje probleme i pokrene mehanizme zajedničkog delovanja. Policija u zajednici predstavlja proaktivnu policiju u kojoj se formalna i neformalna socijalna kontrola međusobno jačaju.

U radu se prezentuju najznačajnija saznanja o ugroženosti kriminalom starih lica od 60 i više godina na teritoriji grada Beograda u periodu od 2015. do 2019. godine, $i$ to u pogledu: vrste krivičnih dela,vremena, mesta, učinioca i sredstva izvršenja, kao i oštećenih lica po polu. Takođe, u radu će se iskazati organizacione, funkcionalne $i$ druge prednosti koncepta policije u zajednici $u$ odnosu na tradicionalan način rada policije $i$ argumentovano predočiti da se njegovom primenom može poboljšati bezbednost starih lica odnosno njegovo delovanje prilagodi bezbednosnim potrebama ove populacije.

Ključne reči: ugroženost starih kriminalom, rad policije u zajednici, prevencija, socijalno ugrožene grupe.

Submitted to the editor -30.03 .2021$

Reviewed-29.05.2021 
Accepted for printing - 08.07.2021

Подано до редакиії - 30.04.2021

Рецензовано - 29.05.2021

Прийнято до друку - 08.07.2021

p 